AGRICULTURE AND BIOLOGY JOURNAL OF NORTH AMERICA

ISSN Print: 2151-7517, ISSN Online: 2151-7525, doi:10.5251/abjna.2011.2.8.1194.1200

(C) 2011, ScienceHu $\beta$, http://www.scihub.org/ABJNA

\title{
Effect of the individual coefficients of inbreeding and grading calculated at different ancestral generations of pedigree regarding body proportions of Shagya horses
}

\author{
Iliana Sabeva
}

Agricultural Institute, Shumen, Bulgaria

\begin{abstract}
The objectives of the present study were to investigate the effect of the inbreeding and the rate of genetic plasma from Arabian breed regarding the body proportions in real Shagya population. The analyses of variance of the indexes for bone system development, compactness, massiveness and chest development and estimations of the levels of factors were made by regression, classification and mixed linear models. The individual inbreeding coefficient and grading induced a considerable variance regarding the body proportions during the study. Their use as linear and non-linear regressions or classification factors in the structure of linear models led to a considerably reduction of the rate of an unexplained variance. The nonlinear effect of the inbreeding was statistically proved regarding the chest index at 6-months of age, the massiveness at 1-year of age, and the bone system development and the body compactness at 3 -years of age. The grading calculated in the $\mathrm{V}^{\text {th }}$ and $\mathrm{VI}^{\text {th }}$ generation of pedigrees was an important source of variation in the late postnatal growth concerning the chest and bone system development. The grading in the $\mathrm{IV}^{\text {th }}$ generation of pedigrees was significant for a description of the variance of compactness. Synergetic effect was established of the linear and quadratic regressions for the grading calculated in the $\mathrm{V}^{\text {th }}$ and $\mathrm{VI}^{\text {th }}$ generation of pedigrees in the chest index. The interactions between the grading from the studied generations of pedigrees were sources of a specific variance regarding the bone system development and the interactions between the grading and inbreeding calculated in the $\mathrm{VI}^{\text {th }}$ generation of pedigrees induced a variety regarding the massiveness. It was established an increased sensitiveness of the massiveness to higher levels of complex inbreeding increasing the grading.
\end{abstract}

Keywords: inbreeding, cross, interactions, soundness, Shagya

\section{INTRODUCTION}

Related mating was a routine method in the improvement of animals and their productive qualities. The increased homozygoteness, which was the main genetic effect from inbreeding, determined: the appearance of recessive genes effect, the creation of a similar genotypic and phenotypic related groups and a differentiation of the based population in to different lines and families /Falconer 1964, 1985; Hinkovsky et al., 1975, etc/. This resulted an analyzing role of inbreeding regarding the recessive genes which could be eliminated from the selection and the universal method of increasing genetic changeability of population by mating of individuals from genetically homogeneous but different genealogical groups /lines and families/.

The inbreeding measured by $F_{i}$ (individual coefficient of inbreeding) and $\Delta \mathrm{F}$ (increasing of homozygoteness of the population for one generation) was an object of permanent scientific researches. There was a prevalence of research works about the inbreeding depression for body measurements of horses and their performance (Pern 1978, Klemetsdal 1998, Gomes et al. 2009, etc). The conclusions from the different studies on the inbreeding depression were not identical and depended on the genetic nature of the studied trait as well as on the different breed tolerance to the increased homozygoteness. The use of the coefficients of inbreeding in the equation of mixed models led to an enhanced accuracy of the variance components estimations, phenotypic and genotypic parameters and of the animals' breeding value (Umari and Kennedy 1990, Wall et al. 2005, Gutierres et al. 2008). Questions of present interest are researches concerning the genetic structure of the population (Luis et al. 1992, Meuwissen and Luo 1992, Moureaux et al. 1995, Glazewska 2004, Man 
W.Y.N. et al. 2007, Cervantes et al. 2008) and the use of $F_{i}$ and $\Delta F$ for establishing the effective size of population from pedigree (Wray and Thompson 1990, Woolliams et al. 1993, Bijma et al. 2001, Gonzalez Recio et al. 2007, Gutierres et al. 2008, etc).

Shagya has a statute of a vulnerable breed. In 2007 ISG accepted some changes in General Studbook Regulations which allowed a registration of horses with grading up to $43.75 \%$ in the $4^{\text {th }}$ generation of pedigrees (less than 7 ancestors are Shagya Araber). Such horses can be registered in the Appendixes to the Main Stallion Book and Main Mare Book.

Through noble crossing new components of heredity are introduced, the genealogical structure of breeds is expanded and some traits are improved. The including of new components of heredity from Arabian breed leads to the greater genetic variety in population, the better type, exterior and performance of horses.

The theoretical aspects of inbreeding and noble crossing were explained long ago but their practical application remains a non-standard, dynamic and creative process. The schemes with a proved efficiency based on the classical doctrines demanded an appropriate concentration of animals in the active breeding herds. Such an approach was difficult to be realized in Shagya horses because of the big dispersion of the breeding material in one country as well as in the whole world. Here it is the knowledge for the effect of the different sources of changeability and their levels on the phenotypic variety of the traits would make defining the couples of mating easier for breeders.

The aim of the present study was to establish the effect of the individual coefficient of inbreeding and the grading on variance of basic body proportions.

\section{MATERIAL AND METHODS}

The objectives of the study were to examine the variance of the indexes characterizing the bone system development, the compactness of the body, the massiveness and the chest development of Shagya horses, born in the last two generations in Kabiuk Stud $/ n=233 /$. The set of data comprised the breeding activity of 15 sires and 47 broodmares, originated from 8 genealogical lines. Their progeny belonged to 18 classes of an interaction between the mother's linear belonging and the distance of descendants' generation from the founder of the corresponding family.
The indexes are percentage ratio between the cannon girth to height at the withers for the bone system development; the chest girth(circumference) to body length for compactness; of the chest girth to height at the withers for massiveness and the width to the depth of the chest for the chest development. The individual coefficients of inbreeding were expressed using a formula first derived by the famous geneticist Wright (1921) to the sixth generation of the pedigree inclusive. The rate of the genetic plasma from Arabians $(G)$ was calculated in percentage in $4^{\text {th }}$ $\left(G_{I V}\right), 5^{\text {th }}\left(G_{I V}\right)$ and $6^{\text {th }}\left(G_{V I}\right)$ generation of the pedigree.

The analyses of variance of body indexes and the estimations of the levels of the factors were done by regression, classification and mixed linear models. Models with a different structure containing linear and quadratic co-variables of $F_{i}$ and $(G)$ were examined. The addition of $F_{i}$ and $G$ as class variables was separately analyzed. The horses were classified according to their level of inbreeding and were assigned to 1 of 8 groups: $F=0.00, F \leq 0.39$, $0.40 \leq \mathrm{F} \leq 0.78, \quad 0.79 \leq \mathrm{F} \leq 1.56, \quad 1.57 \leq \mathrm{F} \leq 2.34$, $2.35 \leq \mathrm{F} \leq 3.12,3.13 \leq \mathrm{F} \leq 3.90, \mathrm{~F} \geq 3.90$; according to $\mathrm{G}$ were assigned to 1 of 4 groups: to $25 \%$, from 31.25 to $43.75 \%$, from 50.00 to $68.75 \%$ and over $75 \%$. The value of intra-class correlations was calculated by the iterative procedure MINQUE /Harvey 1990/.

A larger set of data containing an information about the last 4 generations $/ n=257 /$ was used for defining the effect of interactions between the grading from different generations of pedigree and between the grading and inbreeding. The subclasses of the years of birth were absorbed while the generation of the probands took part in an interactive relation with the mothers' genealogical effect.

Characteristics of the manner of selection in National Stud "Kabiuk".

The breeding of half-thoroughbred Arabian horses in the National Stud "Kabiuk" dated from 1894. A genealogical structure of the breed has been gradually built. The number of formed lines and families was enough to support sufficient genetic similarity among the individuals without being practiced a close-related mating. Each line has been progressing by successful combinations with mares from different lines and families, called genealogical complexes. The family gifted mares completed the qualities of the sires from the lines (without changing lines' profile). Noble crossing with Arabian stallions has been periodically used. Infusion of blood from 
Arabians contributed for a consolidation of well expressed east typicality of Shagya horses in Bulgaria. In spite of the small size of population, the described method of breeding gave sets of data with high level of connectedness among subclasses of the genetic and non-genetic factors.

Since 1989 Bulgaria is a member of ISG.

\section{RESULTS AND DISCUSSION}

The proportions of the body characterize the constitutional strength and soundness of the horses. The average values of indexes in Table. 1 define that the studied population belongs to the lighter type of the breed, raised in the Middle and the East Europe. The well expressed compactness is due to the strong influence of the imported Arabian and halfthoroughbred Arabian horses from Poland and Russia in the past. Many of these horses became founders of lines and families. Some of created at that time lines and families still exist nowadays.

The phenotypic and genotypic correlations between the indexes of the studied set of data have low and average values (not shown here). Consequently indirect selection would not be appropriate even when some of the traits are a function of the same body measurement (massiveness and compactness). Male superiority to female has been +0.20 for the body system development, +0.50 for the compactness, +0.90 for the massiveness and +0.72 for the chest development.

The analyses of the variance of the traits were made according to the age categories (Table. 2). The models for estimation of the variance of the traits at 6 months of age differed from the models of the other ages by giving account of the individual mothers' effect. With different degrees of probability, the inbreeding influenced the variability of massiveness and chest development at 6 months and 1-year of ages, and of bone system development at 1- and 3years of ages. The non-linear effect of inbreeding was statistically proved regarding to the chest index at 6 months of age, the massiveness at 1-year of age, as well as the bone system development and the compactness at 3-years of age.

One of the main reasons for the differences in the degree of significance of the factor inbreeding at the different ages was the selection carried out in a real population. The cull extent was $23.18 \%$ from 6 months to 1 -year of age, $28.49 \%$ from 1-year to 3 years of age or totally $51.67 \%$. The horses with a disproportionate chest development and other big defects were culled on the first stage of selection and horses with insufficient massiveness were also culled to the 3-years of age. The lack of a statistically proven influence of inbreeding regarding to the bone system development at 6 months of age was a result from the strong expressed mother variance and the variance due to the grading in the IV and the $\mathrm{V}$ generation of the pedigrees. According to the data in Table. 2, the $G_{V}$ and $G_{V I}$ were important sources of variation in the late postnatal growth for the chest and the bone system development. The grading calculated to IV generation of pedigrees was important chiefly for the description of the variance of compactness.

The mathematically proved linear regression effects were positive in value except for those of the compactness and for $G_{V}$ of the bone system development (Table. 3). Regarding bone system development, the correspondent non-linear regressions were lower in value in comparison with the linear ones and were opposed in direction. Synergetic effect of linear and non-linear regressions was ascertained for the $G_{V}$ and $G_{V I}$ for the chest index. To make the interpretation of the real regression effect of the grading more clearly, we have to point out that one ancestor brings the increase of the descendants' grade with $6.25 \%$ in IV generation, with $3.12 \%$ in the $\mathrm{V}$ generation and with $1.56 \%$ in the VI generation of pedigree.

During the studied period the values of the individual coefficient of inbreeding ranged from $0.39 \%$ to $8.68 \%$. Only $1.66 \%$ of the horses had $F_{i}$ bigger than $5 \%$. The higher coefficients of inbreeding were a result of the complex inbreeding use for several generations. Complex inbreeding is a form of moderate and distant related mating which contributes to concentration of valuable ancestors in the pedigree and to generate genealogical groups' effects.

The estimations of the different classes of inbreeding are presented in Table. 4. The data showed that levels of inbreeding up to $1.56 \%$ had a negative influence on the body configuration. The tolerance of the bone system development index to the inbreeding was a little bit higher - to $2.34 \%$ at 3-years of age. The non-linear effect of the inbreeding was more significant regarding to the chest and massiveness indexes at 6-months of age.

The interactions between the grading rates of the studied generations of the pedigree were sources of mathematically proved specific variance only for bone 
system development (Table. 5). The horses with $\mathrm{G}$ at the $\mathrm{IV}^{*} \mathrm{~V}^{*} \mathrm{VI}$ from $25.00 \%$ to $43.75 \%$ had the best bone system development, followed by the classes $31.25 \%-50.68 .75 \%$ and $25.00 \%-43.75 \%$. A low positive effect was established for the classes $50.00 \%$ - $68.75 \%$ and $50.00 \%$ - up to $75.00 \%$. According to the given results under suitable choice of Arabian stallions the crossbreeding wouldn't have reduced the index value in the breeding populations. pedigrees was statistically proved regarding to the massiveness. The combinations $G$ to $25 \%{ }^{*} F_{i} 1.57 \%$ - 2.34\%, G 31.25\% - 43.75\%* $F_{i} 0.00 \%-3.12 \%$, G $50.00 \%-68.75 \% * F_{i} 0.00 \%-1.56 \%$ and $G$ up to $75.00 \%{ }^{*} F_{i} 0.39 \%-1.56 \%$ received BLUE-constants above the average for the herd. The data show an increased sensitiveness of the massiveness to higher levels of complex inbreeding increasing the rate of grading.

The effect of interactions between grading and inbreeding calculated to $\mathrm{VI}$ generation of the

Table 1: Overall mean (\%), standard deviation and coefficients of variation of the examined traits at three years of age.

\begin{tabular}{|l|c|c|c|}
\hline Indexes & Mean \pm s.d. & CV & Mean (Karaivanov, 1971) \\
\hline Bone system development & $12.37 \pm 0.28$ & 2.34 & 12.20 \\
\hline Compactness & $115.95 \pm 2.12$ & 1.83 & 116.68 \\
\hline Massiveness & $113.33 \pm 2.41$ & 2.13 & 114.84 \\
\hline Chest development & $59.38 \pm 4.30$ & 7.24 & 57.90 \\
\hline
\end{tabular}

Table 2: Anova of the examined traits.

\begin{tabular}{|c|c|c|c|}
\hline \multicolumn{4}{|c|}{ 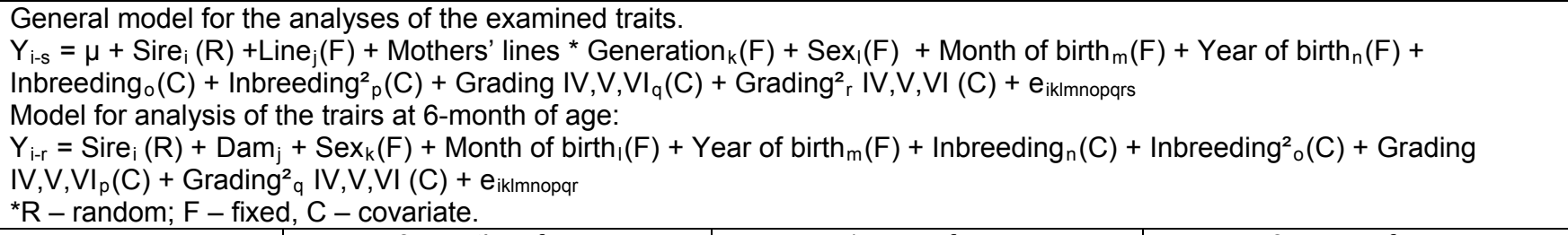 } \\
\hline & 6-months of age & 1-year of age & 3-years of age \\
\hline $\begin{array}{l}\text { Bone system } \\
\text { development }\end{array}$ & $\begin{array}{l}\text { Dam }{ }^{++}, \text {Year of birth }{ }^{+} \\
\text {Grading }^{\mathrm{IV}^{++}}, \text {Grading }^{2} \mathrm{IV}^{++} \\
\text {Grading }^{2} \mathrm{~V}^{++} \\
\text {intra-class correlation }=0.254\end{array}$ & $\begin{array}{l}\text { Line }{ }^{+}, \text {Inbreeding }^{+} \text {, Grading IV } \\
++, \text { Grading }^{2} \mathrm{~V}^{+}, \text {Grading }^{2} \mathrm{VI}^{+}\end{array}$ & $\begin{array}{l}\text { Mothers' lines }{ }^{*} \text { Generation }^{+} \\
\text {Year of birth } \\
\text { Inbreeding }^{2^{+}}, \text {Grading }^{2} \mathrm{IV}^{+} \\
{\text {Grading } \mathrm{V}^{+} \text {.Grading }}^{2} \mathrm{~V}^{+} \\
\text {Grading } \mathrm{VI}^{++}, \text {Grading }^{2} \mathrm{VI}^{++} \\
\text {intra-class correlation }=0.182\end{array}$ \\
\hline Compactness & $\begin{array}{l}\text { Grading } \mathrm{IV}^{+}, \text {Grading }^{2} \mathrm{IV}^{++}, \\
\text {Grading } \mathrm{V}^{+} . \text {Grading }^{2} \mathrm{~V}^{+} \\
\text {Grading VI }^{+}, \text {Grading }^{2} \mathrm{VI}^{+} \\
\text {intra-class correlation }=0.224\end{array}$ & $\begin{array}{l}\text { Mothers' lines * Generation }{ }^{+} \text {, } \\
\text { Sex }^{+}, \text {Year of birth }{ }^{+} \\
\text {intra-class correlation }=0.122\end{array}$ & $\begin{array}{l}\text { Year of birth }{ }^{+}, \text {Mothers' lines * } \\
\text { Generation }{ }^{+}, \text {Sex }{ }^{+}, \text {Grading IV } \\
\text { Inbreeding }{ }^{2^{+}} \\
\text {intra-class correlation }=0.139\end{array}$ \\
\hline Massiveness & $\begin{array}{l}\text { Sex }{ }^{+} \text {, Inbreeding }{ }^{+} \text {, Year of } \\
\text { birth }^{+++}\end{array}$ & $\begin{array}{l}\text { Mothers' lines * Generation }{ }^{+} \text {, } \\
\text { Sex }{ }^{+}, \text {Month of birth }{ }^{++}, \text {Year } \\
\text { of birth }^{+++}, \text {Inbreeding }^{+} \text {, } \\
\text { Inbreeding }^{+} \\
\text {intra-class correlation }=0.136\end{array}$ & $\begin{array}{l}\text { Mothers' lines * Generation }{ }^{+} \text {, } \\
\text { Year of birth }{ }^{++}, \text {Sex }^{+++} \\
\text {intra-class correlation }=0.183\end{array}$ \\
\hline Chest development & $\begin{array}{l}\text { Line }^{++}, \text {Sex }^{+}, \text {Year of birth } \\
\text { Inbreeding }^{++}, \\
\text {Inbreeding } \\
{ }^{+++} \\
\text {intra-class correlation }=0.118\end{array}$ & 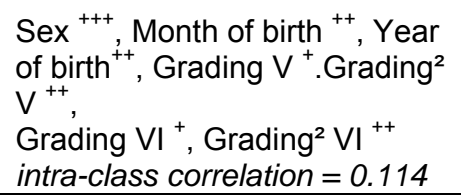 & 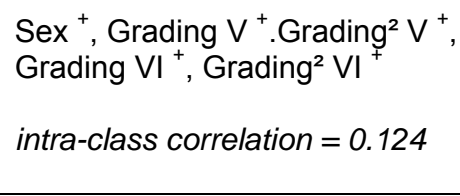 \\
\hline
\end{tabular}


Agric. Biol. J. N. Am., 2011, 2(8): 1194-1200

Levels of significance: $+-P \leq 0.05,++-P \leq 0.01,+++-P \leq 0.001$.

Table 3: Regression coefficients between inbreeding, grading and examined traits at 3-years of age.

\begin{tabular}{|l|c|c|c|c|}
\hline Individual degrees of: & $\begin{array}{l}\text { Bone system } \\
\text { development }\end{array}$ & Compactness & Massiveness & Chest development \\
\hline Inbreeding & $\mathbf{0 . 5 7 6}$ & 2.365 & 3.018 \\
\hline Inbreeding & $\mathbf{- 0 . 0 9 5 ^ { + }}$ & $-\mathbf{0 . 5 2 0 ^ { + }}$ & -0.532 & -0.396 \\
\hline Grading IV & 0.133 & $-\mathbf{2 . 1 8 0 ^ { + + }}$ & -1.056 & -2.567 \\
\hline Grading IV & $\mathbf{- 0 . 0 0 2 ^ { + }}$ & 0.014 & 0.002 & -0.033 \\
\hline Grading V & $\mathbf{- 0 . 0 4 1 ^ { + }}$ & 4.367 & 0.685 & $1.730^{+}$ \\
\hline Grading V & $\mathbf{0 . 0 0 7 ^ { + }}$ & -0.031 & 0.002 & $\mathbf{0 . 0 0 1}^{+}$ \\
\hline Grading VI & $\mathbf{0 . 5 7 1 ^ { + + }}$ & -2.61 & 0.474 & $\mathbf{2 . 9 1 7}^{+}$ \\
\hline Grading VI & $\mathbf{- 0 . 0 0 4 ^ { + + }}$ & 0.020 & -0.005 & $\mathbf{0 . 0 0 4}^{+}$ \\
\hline
\end{tabular}

Levels of significance: $+-\mathrm{P} \leq 0.05,++-\mathrm{P} \leq 0.01$.

Table 4: Effects of individual coefficient of inbreeding.

\begin{tabular}{|c|c|c|c|c|c|c|c|c|}
\hline \multirow[t]{3}{*}{$\begin{array}{l}\text { Levels of } \\
\text { inbreeding }\end{array}$} & \multicolumn{2}{|c|}{ Chest development } & \multicolumn{4}{|c|}{ Massiveness } & \multirow{2}{*}{\multicolumn{2}{|c|}{$\begin{array}{l}\begin{array}{l}\text { Bone system } \\
\text { development }\end{array} \\
\text { 3-years of age }\end{array}$}} \\
\hline & \multicolumn{2}{|c|}{ 6-months of age } & \multicolumn{2}{|c|}{ 6-months of age } & \multicolumn{2}{|c|}{ 1-year of age } & & \\
\hline & $\mathrm{n}$ & BLUE-constant & $\mathrm{n}$ & BLUE-constant & $\mathrm{n}$ & BLUE-constant & $\mathrm{n}$ & BLUE-constant \\
\hline $0.00 \%$ & 46 & 1.20 & 46 & 1.32 & 29 & 1.59 & 20 & 0.11 \\
\hline to $0.39 \%$ & 15 & 2.26 & 15 & 1.06 & 11 & 2.18 & 9 & -0.17 \\
\hline $0.40-0.78 \%$ & 16 & 3.25 & 16 & 0.96 & 10 & 1.44 & 9 & 0.24 \\
\hline $0.79-1.56 \%$ & 54 & 0.58 & 54 & 1.88 & 43 & 0.08 & 27 & 0.30 \\
\hline $1.57-2.34 \%$ & 28 & -0.10 & 28 & 0.45 & 24 & -1.29 & 15 & 0.33 \\
\hline $2.35-3.12 \%$ & 15 & -0.76 & 15 & -1.26 & 14 & 0.78 & 11 & 0.06 \\
\hline $3.13-3.90 \%$ & 29 & -3.15 & 29 & -0.83 & 26 & -2.25 & 19 & -0.36 \\
\hline Up $3.90 \%$ & 30 & 3.30 & 30 & -3.58 & 22 & -2.53 & 18 & -0.54 \\
\hline inbreeding $^{2}(\mathrm{REG})$ & & $0.20 \pm 0.09$ & & $0.16 \pm 0.09$ & & $0.15 \pm 0.09$ & & $-0.03 \pm 0.04$ \\
\hline$\mu$ & 233 & $55.18 \pm 0.82$ & 233 & $101.71 \pm 0.95$ & 179 & $110.79 \pm 1.27$ & 128 & $12.59 \pm 0.15$ \\
\hline
\end{tabular}

Table 5: Effect of interactions between degrees of grading at IV*V*VI generations of pedigree regarding the bone system development at 3-years of age.

\begin{tabular}{|c|c|c|c|}
\hline \multicolumn{4}{|c|}{ 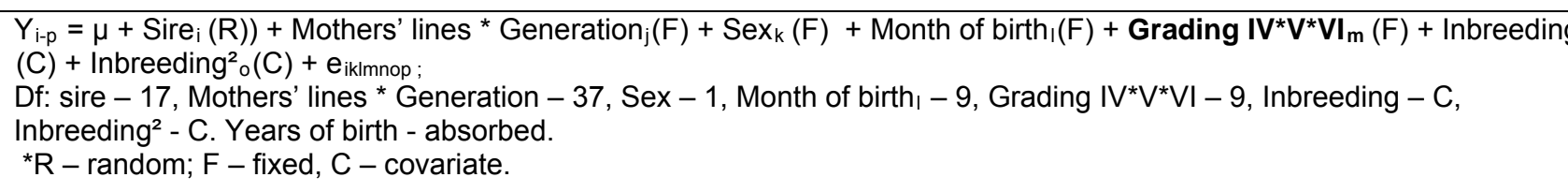 } \\
\hline $\begin{array}{l}\text { Grading at IV*V*VI (\%) } \\
\text { Levels of significance: } P \leq 0.05\end{array}$ & $\begin{array}{l}\text { Stud Book } \\
\text { position }\end{array}$ & $\mathbf{n}$ & BLUE-constant \\
\hline to $25.00 *$ to $25.00 *$ to 25.00 & Main & 26 & -0.037 \\
\hline to $25.00 *$ to $25.00 * 31.25-43.75$ & Main & 22 & 0.280 \\
\hline to $25.00 * 31.25-43.75 * 31.25-43.75$ & Main & 7 & 0.222 \\
\hline $31.25-43.75 * 31.25-43.75 * 31.25-43.75$ & Main & 28 & -0.008 \\
\hline $31.25-43.75 * 31.25-43.75 * 50.00-68.75$ & Main & 4 & 0.032 \\
\hline $31.25-43.75 * 50.00-68.75 * 50.00-68.75$ & Main & 9 & 0.260 \\
\hline $50.00-68.75 * 50.00-68.75 * 50.00-68.75$ & Appendix & 130 & 0.052 \\
\hline $50.00-68.75 * 50.00-68.75 * 75.00$ and up & Appendix & 7 & 0.062 \\
\hline $50.00-68.75 * 75.00$ and up * 75.00 and up & Appendix & 7 & -0.129 \\
\hline 75.00 and up * 75.00 and up * 75.00 and up & Appendix & 17 & -0.150 \\
\hline
\end{tabular}


Table 6: Rate of the explaned variation $\left(R^{2}\right)$ of the examined models.

\begin{tabular}{|c|c|c|c|c|c|}
\hline \multirow[t]{2}{*}{ Examined models } & \multirow[t]{2}{*}{ Age } & $\begin{array}{l}\text { Bone system } \\
\text { development }\end{array}$ & $\begin{array}{l}\text { Compactn } \\
\text { ess }\end{array}$ & $\begin{array}{l}\text { Massive } \\
\text { ness }\end{array}$ & $\begin{array}{c}\text { Chest } \\
\text { developm } \\
\text { ent }\end{array}$ \\
\hline & & $\mathrm{R}^{2}(\%)$ & $\mathrm{R}^{2}(\%)$ & $\mathrm{R}^{2}(\%)$ & $\mathrm{R}^{2}(\%)$ \\
\hline $\begin{array}{l}\text { Regression models that contain linear and nonlinear } \\
\text { covariates of grading and individual coefficient of } \\
\text { inbreeding. }\end{array}$ & $\begin{array}{l}6 \text { month } \\
1 \text { year } \\
2 \text { year } \\
3 \text { year }\end{array}$ & $\begin{array}{c}6.4 \\
17.7 \\
7.6 \\
10.2 \\
\end{array}$ & $\begin{array}{c}7.7 \\
8.9 \\
16.7 \\
17.6 \\
\end{array}$ & $\begin{array}{c}10.5 \\
9.7 \\
16.8 \\
6.4 \\
\end{array}$ & $\begin{array}{c}11.9 \\
16.8 \\
7.2 \\
10.3 \\
\end{array}$ \\
\hline $\begin{array}{l}\text { Classification model with covariates that contain } \\
\text { fixed set of non-genetic effects and linear and } \\
\text { nonlinear covariates of grading and individual } \\
\text { coefficient of inbreeding. }\end{array}$ & $\begin{array}{l}6 \text { month } \\
1 \text { year } \\
2 \text { year } \\
3 \text { year }\end{array}$ & $\begin{array}{l}21.8 \\
50.0 \\
47.5 \\
56.6\end{array}$ & $\begin{array}{l}21.6 \\
43.9 \\
55.0 \\
73.4\end{array}$ & $\begin{array}{l}42.9 \\
60.0 \\
55.8 \\
69.5\end{array}$ & $\begin{array}{c}21.3 \\
48.6 \\
44.9 \\
51.50\end{array}$ \\
\hline $\begin{array}{l}\text { Mixed models that contain genetic non-interacting } \\
\text { random effect, interaction of group effects and linear } \\
\text { and nonlinear covariates of grading and individual } \\
\text { coefficient of inbreeding. }\end{array}$ & $\begin{array}{l}6 \text { month } \\
1 \text { year } \\
2 \text { year } \\
3 \text { year }\end{array}$ & $\begin{array}{l}57.0 \\
70.4 \\
64.3 \\
88.0\end{array}$ & $\begin{array}{l}42.6 \\
56.7 \\
68.4 \\
94.0\end{array}$ & $\begin{array}{l}58.9 \\
72.9 \\
71.9 \\
90.7\end{array}$ & $\begin{array}{l}50.1 \\
61.4 \\
60.7 \\
70.1\end{array}$ \\
\hline
\end{tabular}

The magnitude of the explained variance of the traits described by different types of linear models is given in Table 6. The comparison was made on the basis of the value of the multiple correlation coefficient $\left(R^{2}\right)$ which indicated appropriateness of the models and gave information about the interrelation between explained and residual variance (Schaeffer, 1993). The regression models, containing the linear and non-linear effects of inbreeding and grading depending on the age described to $17.7 \%$ of the variance of the bone system development, to $17.6 \%$ of the variance of the compactness and to $16.8 \%$ of the variance of the massiveness and chest indexes. Bearing in mind the low phenotypic variance of the traits in long time selected populations with limited genetic pool, where the independent progressive selection has applied, such size of variation must not be neglected in the statistical analyzes. The classification models with the same co-variables explained the variation of the compactness and massiveness satisfactorily, where the influence of years was strongly expressed Table 2 . The using of the interaction between the mothers' line belonging and descendants' generation in mixed models, based on the covariance between the paternal half-sibs, increased their appropriateness with $31.4 \%$ regarding bone system development and about $20 \%$ for the rest of the traits.

\section{CONCLUSIONS}

The individual coefficients of inbreeding and grading induced a considerable variance regarding the body proportions during the study. Their use as linear and non-linear regressions or classification factors in the structure of linear models led to considerable reduction of the rate of the unexplained variance. The degrees of complex inbreeding up to $1.56 \%$ had negative influence on the body configuration in many of the cases. The tolerance of the bone system development index to inbreeding was a little higher to $2.34 \%$ at 3 -years of age. The non-linear effect of inbreeding was statistically proved regarding to the chest index at 6 months of age, the massiveness at 1 -year of age, as well as to the bone system development and compactness of the body at 3years of age.

The grading calculated in the $\mathrm{V}^{\text {th }}$ and $\mathrm{VI}^{\text {th }}$ generation of pedigrees was an important source of variation in the late postnatal growth concerning chest and bone system development. The grading in the $\mathrm{IV}^{\text {th }}$ generation of pedigrees was essential for the description of the variance of compactness only. Synergetic effect was established of the linear and quadratic regressions for the grading in the $\mathrm{V}^{\text {th }}$ and $\mathrm{VI}^{\text {th }}$ generation of pedigrees in the chest index.

The interactions between the grading from the studied generations of pedigrees were sources of specific variance regarding the bone system development. The interactions between grading and inbreeding to the $\mathrm{VI}^{\text {th }}$ generation of pedigrees induced a variety regarding the massiveness. It was established an increased sensitiveness of the massiveness to higher levels of complex inbreeding increasing the degree of grading.

\section{REFERENCES}


Bijma* P., J. A. M. Van Arendonk* and J. A. Woolliamst. (2001). Predicting rates of inbreeding for livestock improvement schemes. J. Anim. Sci. 79:840-853.

Cervantes I., A. Molina, F. Goyache, Gutierrez J. P., M. Valera. (2008). Population history and genetic variability in Spanish Arab horse assessed via pedigree analysis. Livestock Science, 113: 24-33.

Falconer D. S. (1989). Introduction to quantitative genetics. Longman, London and NY, $340 \mathrm{p}$.

Głażewska I. (2004). Mating and selection in National Arabian Horse breeding: inbreeding coeficients analysis. EJPAU 7(1), № 02.

Gonzalez-Recio O., E. Lopes de Maturana, EJ. P. Gutierrez. (2007). Inbreeding depression on female fertility and calving ease in Spanish dairy cattle. Journal of Dairy Science, 90: 5744-5752.

Gomez M. D., M. Valera, A. Molina, J.P. Gutierrez, F. Goyache. (2009). Assessment of inbreeding depression for body measurements in Spanish (Purebred) horses. Livestock Sience, 122: 149-155.

Hinkovsky Tz., I. Vasileva, I. Venev. (1975). Genetic basis of selection in animal husbandry. Zemizdat, Sofia, pp. 270. $(\mathrm{Bg})$

Karaivanov R., A. Petrov, D. Dobrev, Tz. Tzankov.(1971). Trail to standard the horses in Bulgaria.Sofia, pp. 129. (Bg)

Klemetsdal Gunnar. (1998). The effect of inbreeding on racing performance in Norwegian cold-blooted trotters. Genet. Sel. Evolution, 30: 351-366.

Luis Cristina, E. Gus Cothran, Maria do Mar OOM. (1992). Inbreeding and genetic strucure in endangwred Sorraia Breed: Implications for its conservation and menagement.Journal of animal Sience, 70(3): 656672.
Man W.Y.N., F.W. Nicolas, J. W. James. (2007). Apedigree-analysis aproach to the descriptive epidemiology of autosomal-recessive disorders. Prevent. Vet. Med., 78: 262-273.

Meuwissen T. H. E., Z. Luo. (1992). Computing inbreeding coefficients in large population. Gen. Sel. Evol., 24:305-313.

Moureaux Sophie, Anne Ricard, Etienne Verrier. (1995). Inbreeding and probabilities ofgenes origin in five French race and riding horse breeds. 46th An.Meeting of he EAAP, Prague, $8 \mathrm{p}$.

Pern E. M. (1978). Genetic Basis of improvement with Thoroughbreds in USSR. Scientific papers of VNIIK, vol. 31: 126-170. (Ru)

Schaeffer L. R. (1993). Linear models and computing strategies in Animal Breeding.University of Guelph, Ontario, pp.192.

Umari P., B. W. Kennedy. (1990). Mixed model methodology to estimate additive and dominance genetic values under complete dominance and inbreeding. Proc. $4^{\text {th }}$ World Cong. Appl. Livest. Prod., 13: $297-300$.

Wall E., S. Brotherstone, J. F. Kearney, J. A. Woolliams, M. P.Coffey. (2005). Impact of nonadditive genetic effects in the estimation of breeding values for fertility and correlated traits. Journal of Dairy Science, 88(1): 376385.

Woolliams J.A., N. R.Wray, R. Thompson.(1993). Prediction of long-term contributions and inbreeding in populations undergoing mass selection. Gen. Res., 62:231-242.

Wray N. R., R. Thompson.(1990). Prediction of rates of inbreeding in selected populations. Gen. Res., 55: 4154. 